\title{
The Relationship Between Body Mass Index with Body Fat Percentage of Participants EXPO 2021 Universitas Teuku Umar
}

\author{
${ }^{1}$ Suci Eka Putri, ${ }^{2}$ Adelina Irmayani Lubis \\ ${ }^{1}$ Universitas Teuku Umar, Indonesia, suciekaputri@utu.ac.id \\ ${ }^{2}$ Universitas Teuku Umar, Indonesia, adelina.irmayani@utu.ac.id \\ Coresponding author : Suci Eka Putri, e-mail : suciekaputri@utu.ac.id
}

\begin{abstract}
Body mass index (BMI) is to monitor nutritional status adults, especially those related to deficiency and overweight. Body fat percentage can describe the risk of degenerative diseases. This study was conducted to measure the relationship between BMI and body fat percentage. Methods an analytical study was conducted to 41 male and 51 female participant from Universitas Teuku Umar. The body weight was measured using scales, whereas the body height was measured using microtoise. The body fat percentage was measured using Karada Scan. The BMI was calculated by dividing the body weight in kilogram divided by body height in meter square. Data was collected from 16-18 February 2021 and analyzed by Pearson's correlation test. The results showed BMI underweight, normal, and overweight were 10.9, 57.6, and 31.5. High body fat percentage in men were $75.6 \%$ and in women were $35.5 \%$. There is a relationship between the nutritional status of the women group and the body fat percentage with p-value is obtained = 0.021 . Furthermore, for men, there is no relationship between nutritional status in the men group and the body fat percentage. There is a relationship between nutritional status and body fat percentage in women. Among this population, BMI can still be used to determine body fat percentage.
\end{abstract}

\section{ARTICLE INFORMATION}

Submitted: $30 / 04 / 2021$

Revised: 20/05/2021

Accepted: $27 / 05 / 2021$

Publish Online: 28/05/2021

\section{Keywords:}

BMI

Body Fat Percentage

How to cite this article: Putri, S.E. and Lubis, A.I. (2021). The Relationship Between Body Mass Index with Body Fat Percentage of Participants EXPO 2021 Universitas Teuku Umar. JNS: Journal of Nutrition Science, 2(1), 13-18

\section{Introduction}

Obesity occurs due to an increase in fat in the body that can affect health (Robeiro, 2014). Level of fat mass in male $13-21 \%$ and female $23-31 \%$ (Gibson, 2005).

Nutritional status is often related to the intake of food consumed. If the nutritional intake over the requirement per day, it can affect nutritional status. Over or insufficient food intake will cause changes in body composition, namely increase / decrease in body weight, body fat percent and muscle mass. According to Wiknjosatro (2005) and Handayani et al (2013), there is a significant relationship between nutritional status based on Body Mass Index (BMI) with body fat percent where fat nutritional status has a close relationship with high body fat percent (Handayani, 2013; Wiknjosastro, 2005). Excess body fat percent can affect the endurance of the cardiovascular system, body composition, muscle endurance, muscle strength, and flexibility (Truter L, 2010). Besides that according to research, body fat percent is a predictor variable for bone density (Nafilah Nafilah \& Fitranti).

The body fat percentage variable was chosen because this variable is an indicator of anthropometric measurements of nutrition and can describe the ratio of fat mass to fat-free mass in a person's body (Gibson, 2005). Body Fat percentage is a better predictor of diabetes and cardiovascular events than BMI (Naval K. Vikram et al., 2016). This study aims to know the relationship between BMI and Body Fat in different genders. 
Available at http://jurnal.utu.ac.id/jons/article/view/3567

Method

Population and subjects of this study are all participants EXPO 2021 of the Universitas Teuku Umar, selected using stratified random sampling method. This study was conducted from 16-18 February 2021 at Universitas Teuku Umar. This study used a cross-sectional design because the measurement of the dependent variable and the independent variable of the study was carried out at the same time.This research is descriptive analytic, which is looking for the relationship between body mass index and body fat percentage.

The dependent variable in this study is body fat percentage and variable independent is body mass index. Body height measurement in this study used stature meter tool, while body weight measurement and body composition determination used Karada scan.

The data obtained were then analyzed using SPSS software. Univariate analysis was performed to identify age, sex, body mass index and percent body fat. Bivariate analysis Pearson Chi square test, the relationship between body mass index and body fat percentage.

\section{Results}

Respondent characteristics discussed in this study were age, sex, and nutritional status of respondents.

Table 1. Characteristic of Respondens

\begin{tabular}{lc}
\hline Characteristic & n \\
\hline Age & \\
$15-20$ & 25 \\
$21-26$ & 20 \\
$27-32$ & 10 \\
$33-38$ & 14 \\
$39-44$ & 12 \\
$45-49$ & 4 \\
$50-55$ & 4 \\
$56-61$ & 3 \\
Sex & \\
Male & 41 \\
Female & 51 \\
Nutritional Status & \\
Uderweight (Below 18,5) & 10 \\
Normal (18,5-25,0) & 53 \\
Overweight (25,1 and above) & 29 \\
\hline Total & 92 \\
\hline
\end{tabular}

The sample characteristics observed were age, sex, and nutritional status. Based on Table 1. highest age category of respondents is in the 15-20year age group as much as $27.2 \%$. The lowest age group is found in $56-61$ years as much as 3,3\%. Female are higher than men, namely as much as 55,4\%. The nutritional status of respondents is known to be the highest, namely normal as much as $57,6 \%$ and the lowest with a thin nutritional status of $10.9 \%$.

Table 2. Frequency Distribution Category of Body Fat Percentage

\begin{tabular}{lcc}
\hline Body Fat Percentage & Total & \% \\
\hline Men & & \\
High $(\geq 20 \%)$ & 31 & 75.6 \\
Normal and low $(<20 \%)$ & 10 & 24.4 \\
Female & & \\
High $(\geq 30 \%)$ & 18 & 35.3 \\
Normal and low $(<30 \%)$ & 33 & 64.7 \\
\hline
\end{tabular}

In males, it was found that the percentage of body fat was very high with the category $\geq 20 \%$, namely 31 people $(75.6 \%)$ and the normal and low percentage categories were 10 people $(24.4 \%)$. In female, the highest percentage of body fat was in the normal and low categories $(<30 \%)$, namely as much as $64.7 \%$, while the high was $35.3 \%$.

Table 3. Pearson Test Result for Relation Between Nutritional Status and Body Fat Percentage

\begin{tabular}{|c|c|c|c|c|c|c|}
\hline \multirow[t]{3}{*}{$\begin{array}{c}\text { Nutritional } \\
\text { Status }\end{array}$} & \multicolumn{3}{|c|}{$\begin{array}{c}\text { Body Fat } \\
\text { Percentage }\end{array}$} & \multirow{2}{*}{\multicolumn{2}{|c|}{ Total }} & \multirow[t]{3}{*}{$\begin{array}{c}p \\
\text { value }\end{array}$} \\
\hline & High & & $\begin{array}{l}\text { nal } \\
\text { cow }\end{array}$ & & & \\
\hline & $\%$ & n & $\%$ & n & $\%$ & \\
\hline
\end{tabular}

Male

\begin{tabular}{|c|c|c|c|c|c|c|c|}
\hline $\begin{array}{l}\text { Underweight } \\
\text { (Below 18.5) }\end{array}$ & 1 & 2.4 & 2 & 4.9 & 3 & 7.3 & \multirow{3}{*}{0.083} \\
\hline $\begin{array}{l}\text { Normal } \\
(18.5-25.0)\end{array}$ & 14 & 34.1 & 6 & 14.6 & 20 & 48.7 & \\
\hline $\begin{array}{l}\text { Overweight } \\
\text { ( } 25.1 \text { and } \\
\text { above) }\end{array}$ & 16 & 39.1 & 2 & 4.9 & 18 & 44.0 & \\
\hline \multicolumn{8}{|l|}{ Female } \\
\hline $\begin{array}{l}\text { Underweight } \\
\text { (Below 18.5) }\end{array}$ & 0 & 0 & 7 & 13.7 & 7.0 & 13.7 & \\
\hline $\begin{array}{l}\text { Normal } \\
(18.5-25.0)\end{array}$ & 11 & 21.6 & 22 & 43.2 & 33 & 64.8 & \multirow[t]{2}{*}{0.021} \\
\hline $\begin{array}{l}\text { Overweight } \\
\text { ( } 25.1 \text { and } \\
\text { above) }\end{array}$ & 7 & 13.7 & 4 & 7.8 & 11.0 & 21.5 & \\
\hline
\end{tabular}


In Table 3, in women, the p-value is obtained 0.021, which means that there is a relationship between the nutritional status of the female group and the body fat percentage. Furthermore, for male, the $\mathrm{p}$ value $=$ 0.083 , which means that there is no relationship between nutritional status in the male group and the body fat percentage.

\section{Discussion}

In this study, there was a relationship between nutritional status and percent body fat in women, but in men there was no relationship between nutritional status and percent body fat. This is the same as Chathuranga Ranasinghe's research (2013), there is a significant relationship between BMI-body fat percentage, especially when compared by gender. The relationship between BMI in women is more significant than that of men. In both sexes, with increasing age, BF\% increases linearly. BMI has a strong correlation with BF\% in this sub population of South Asian adults (Ranasinghe, Gamage, Katulanda, Andraweera, \& Tharanga, 2013). The importance of taking age and gender in to consideration when using BMI to predictbody fat percentage/obesity, in a population. According to Misra, et al., there is a strong correlation between $\mathrm{BMI}$ and $\mathrm{BF} \%$ especially at higher BMI and in younger women (P Misra, A K Singh, S Archana, A Lohiya, \& Kant., 2019). Research conducted by Akindele, et al. (2016), show that there is a strong positive association between $\mathrm{BMI}$ and $\mathrm{BF} \%$, and age and sex are predictors of this association (Akindele, Phillips, \& Igumbo, 2016 ). Where Asian women are predicted to have the highest body fat (Mills, 2007).

There was a strong and positive statistical relationship between BF\% and BMI when both were paired without controlling for gender and age $(\mathrm{r}=0,81, \mathrm{P}<0.01)$. A positive and strong correlation between $\mathrm{BF} \%$ and $\mathrm{BMI}$ in males $(\mathrm{r}=0.83, \mathrm{P}<0.01)$ and females $(\mathrm{r}=0.89, \mathrm{P}<0.01)$ was found using Spearman rho rank since the variables were not normally distributed (Akindele et al., 2016 ).

The relationship was significant across all the BMI categories except among individuals whose weight were below normal. Also, the strength of correlation increased with the increase in BMI category with a no significant $r$ of 0.32 in underweight category to $r$ of 0.60 and 0.77 in overweight and obese category, respectively (Meeuwsen S, 2010).

\section{Conclusion}

This study concluded that there is a relationship between nutritional status and body fat percent in women. This is in linear with the number of women who are overweight with high body fat percent, which is $13.7 \%$. In addition, it can be seen that $35.3 \%$ of women have high body fat percent. However, there was no relationship between nutritional status and body fat percent in men. Normalizing nutritional status and body fat percentage, one of which is by maintaining consumption patterns and increasing physical activity.

\section{References}

Akindele, M. O., Phillips, J. S., \& Igumbo, E. U. (2016 ). The Relationship Between Body Fat Percentage and Body Mass Index in Overweight and Obese Individuals in an Urban African Setting. J Public Health Afr, 7(1), 515. doi: 10.4081/jphia.2016.515.

Gibson, R. S. (2005). Principles of nutritional assessment (2nd ed). : Modison Avenue: Oxford University Press.

Handayani, M. S., Cesilia, M. D., Hadi, R. . (2013). Hubungan Komposisi Tubuh dan Status Gizi Dengan Perkembangan Seksual Pada Remaja Putri di Perkotaan dan Perdesaan. Jurnal Gizi dan Pangan, 8(3), 181-186.

Meeuwsen S, H. G., Elia M. . (2010). The Relationship Between BMI and Percent Body Fat, Measured by Bioelectrical Impedance, In A Large Adult Sample is Curvilinear and Influenced By Age and Sex. Clin Nutr, 29(5), 560-566. doi: 10.1016/j.clnu.2009.12.011.

Mills, T. C., Gallagher, D., Wang, J., \& Heshka, S. (2007). Modelling the Relationship Between Body Fat and the BMI. International Journal of Body Composition Research, 5(2), 73-79.

Nafilah Nafilah, \& Fitranti, D. Y. Hubungan Indeks Massa Tubuh (IMT), Persen Lemak Tubuh, Asupan Zat Gizi dan Aktivitas Fisik Dengan Kepadatan. . di : http://ejournalsl.undip.ac.id/index.php/jnc.

Naval K. Vikram, Ahmad Nawid Latifi, Anoop Misra, Kalpana Luthra, Surya Prakash Bhatt, Randeep Guleria, a., \& Pandey., R. M. (2016). Waist-to-Height Ratio Compared to Standard Obesity Measures as Predictor of Cardiometabolic Risk Factors in Asian Indians in North India. METABOLIC SYNDROME AND RELATED DISORDERS. Mary Ann Liebert, Inc., $\quad X X(\mathrm{XX}), \quad 1-8 . \quad$ doi: 10.1089/met.2016.0041. 
Available at http://jurnal.utu.ac.id/jons/article/view/3567

P Misra, A K Singh, S Archana, A Lohiya, \& Kant., S. (2019). Relationship Between Body Mass Index and Percentage of Body Fat, Estimated by Bio-Electrical Impedance Among Adult Females in A Rural Community of North India: A Cross-Sectional Study. J Postgrad Med, 65(13), 134-140. doi: 10.4103/jpgm.JPGM_218_18.

Ranasinghe, C., Gamage, P., Katulanda, P., Andraweera, N., \& Tharanga, S. T. a. P. (2013). Relationship Between Body Mass Index (BMI) and Body Fat Percentage, Estimated By Bioelectrical Impedance, In A Group Of Sri Lankan Adults: A Cross Sectional Study. BMC Public Health, 13(797). doi: 10.1186/1471-2458-13-797

Ranasinghe, C., Gamage, P., Katulanda, P., Andraweera, N., \& Tharanga, S. T. a. P.
(2013). Relationship Between Body Mass Index (BMI) and Body Fat Percentage, Estimated By Bioelectrical Impedance, In A Group Of Sri Lankan Adults: A Cross Sectional Study. BMC Public Health, 13(797). doi: 10.1186/1471-2458-13-797.

Truter L, P. A., Du Toit D. (2010). Relationships Between Overweight, Obesity and Physical Fitness of Nine to Twelve-Year-Old South African Children. SA Fam Pract, 52(3), 227233.

Wiknjosastro, H. (2005). Ilmu kebidanan (3rd Ed ed.). Jakarta: Yayasan Bina Pustaka Sarwono Prawirohardjo. 